\title{
Використання засобів кросфіту у фізичній та професійно-прикладній підготовці військовослужбовців строкової служби
}

\author{
Олександр Петрачков ${ }^{1}$, Олена Ярмак², \\ Василь Білошицький ${ }^{1}$
}

${ }^{1}$ Національний університет оборони України імені Івана Черняховського, Київ, Україна

2 Білоцерківський національний аграрний університет, Біла Церква, Україна

Анотація. На сьогодні, актуальною проблемою військових фахівців є пошук ефективних засобів для підвищення рівня військово-прикладних навичок, загальної та спеціальної фізичної підготовленості військовослужбовців строкової служби. Мета. Визначити вплив засобів кросфіту на фізичну та професійно-прикладну підготовку військовослужбовців строкової служби механізованих підрозділів Сухопутних військ. Методи. Аналіз даних науково-методичної літератури; увагу було приділено науковим роботам, в яких були застосовані засоби кросфіту, педагогічне спостереження; педагогічне тестування фізично підготовленості; педагогічний експеримент; методи математичної статистики. Результати. Визначено, що програма із засобами кросфіту позитивно вплинула на рівень фрізичної та професійно-прикладної підготовки військовослужбовців строкової служби. Використання багатофункціональних засобів кросфіту середньої та високої інтенсивності дало можливість значно покращити рівень основних рухових якостей. Постійна динаміка змісту вправ дозволила використовувати комплекси, які цілеспрямовано були спрямовані на вдосконалення необхідних рухових якостей, які, у свою чергу, впливають на якість бойової та вогневої підготовки. Спостерігається приріст в середньогрупових результатах показників спеціальних та військово-прикладних вправ наприкінці педагогічного експерименту, вірогідні позитивні зміни відбулися у п'яти контрольних тестах. Отримані результати вказують на вагомий вплив засобів кросфіту під час формування необхідних професійно-прикладних якостей у військовослужбовців строкової служби. Достовірна інформація, отримана в ході педагогічного експерименту, може бути використана для написання програми фрізичної підготовки військовослужбовців строкової служби з використанням засобів кросфіту. Ключові слова: кроссріт, військовослужбовці, бойова підготовка, вогнева підготовка, фрізична підготовка, професійно-прикладна підготовка.

\section{Oleksandr Petrachkov, Olena Yarmak, Vasyl Biloshytskyi}

\section{THE USE OF CROSSFIT IN PHYSICAL AND APPLIED PROFESSIONAL TRAINING OF ARMY CONSCRIPTS}

Summary. Today, the urgent challenge for military professionals is the search for effective means to improve the level of applied military skills, general and special physical preparedness of military conscripts. Objective. To determine the effects of crossfit training on physical and applied professional preparedness of conscripts of Ukrainian Army motorized units. Methods. Analysis of the data of scientific and methodological literature; pedagogical observation; pedagogical testing of physical fitness; pedagogical experiment; and methods of mathematical statistics. Results. It was found that the program including crossfit training had a positive effect on the level of physical and applied professional training of military conscripts. The use of moderate and high intensity multifunctional crossfit training made it possible to significantly improve the level of basic motor skills. The constant changes of the content of training exercises allowed the use of exercise sets, which were purposefully focused on improving required motor skills that, in turn, affected the quality of military skills and firing proficiency. An increase was observed in the average group results in special and applied military exercise tests at the end of the pedagogical experiment; significant positive changes occurred in the results of five control tests. The obtained results

Petrachkov 0., Yarmak 0., Biloshytskyi V.

The use of crossfit in physical and applied professional training of army conscripts. Theory and Methods of Physical education and sports. 2021; 3: 74-79

DOI: 10.32652/tmfvs.2021.3.74-79
Петрачков 0., Ярмак О., Білошицький В.

Використання засобів кроссріту у фрізичній та професійно-прикладній підготовці військовослужбовців строкової служби. Теорія і методика фрізичного виховання і спорту. 2021; 3: 74-79 DOI: 10.32652/tmfvs.2021.3.74-79
Вступ. Звертаючи ос обливу увагу на формування професійної армії, враховуючи зміни, які відбуваються в сучасних умовах ведення збройної боротьби, командування Сухопутних військ Збройних сил України надає важливого значення питанням бойової підготовки та професійно-прикладній підготовці військових. Безперервне удосконалення бойової техніки, зброї та засобів ведення бойових дій, перехід військ на нові зразки озброєння, скорочення термінів виконання бойових завдань вимагають від військових фахівців опанування більших обсягів теоретичних знань, практичних умінь та навичок $[10,14]$.

Одним із найважливіших чинників професійної майстерності військовослужбовців є високий рівень їхньої функціональної і ффізичної підготовленості, який забезпечує належне виконання службових обов'язків [2, 4]. Фізична підготовка входить до складу професійної підготовки військовослужбовців, є частиною загальної системи навчання та виховання особового складу Збройних сил України. Результати наукових досліджень та практичний досвід військових фрахівців свідчать, що фізична підготовка $€$ однією $з$ основних дисциплін професійної та бойової підготовки, яка може здійснити певний вплив на успішність навчання, якість бойової підготовки, загальною метою якої є забезпечення фрізичної готовності військовослужбовців до навчально-бойової діяльності, оволодіння зброєю і бойовою технікою та ефективне їх використання, перенесення фрізичних навантажень, нервово-психічних напружень в екстремальних ситуаціях, а також виконання функціональних обов'язків та професійних завдань [3].

Найбільш тісний взаємозв'язок між фрізичною підготовкою та ефективністю оволодіння спеціальними вміннями тапрофесійно-прикладними навичками зареєстровано у військово- 
indicate a significant effect of crossfit training on the development of required applied professiona skills in military conscripts. Reliable information obtained during the pedagogical experiment can be used to develop a physical training program including crossfit training for military conscripts. Keywords: crossfit, servicemen, combat training, fire training, physical training, applied professional training.

службовців, професійна-прикладна підготовка яких пов'язана зі значним обсягом фрізичних навантажень, що має місце у військовослужбовців Сухопутних військ $[5,7]$.

Вплив фрізичної підготовленості особового складу на ступінь бойової готовності підрозділів виявляється безпосередньо через фрізичні можливості військовослужбовців виконувати свої функціональні обов'язки. У мирний час належний рівень фрізичної підготовленості особового складу повинен забезпечити високу ефективність процесу бойової підготовки, бойового чергування і постійну фрізичну готовність виконати бойове завдання. У воєнний час виконання особовим складом своїх професійних обов'язків вимагає такого рівня фрізичної підготовленості, який би забезпечив найбільш ефективне використання бойових властивостей озброєння і техніки, найбільш якісне виконання бойових прийомів і дій протягом тривалого часу. Втрати в живій силі і техніці знаходяться в прямій залежності від уміння якомога довше зберігати високий рівень ефективності дій, що виконуються в бою [2].

Отже, для ефективного виконання професійних завдань система фізичної підготовки військовослужбовців Сухопутних військ повинна містити засоби для розвитку спеціальної та загальної витривалості, спритності, швидкості, швидкісно-силових якостей, координаційних здібностей, сили. На сьогодні актуальним засобом фрормування рівня фізичної готовності до виконання завдань за призначенням може бути високоінтенсивний функціональний тренінг [8, 10, 11]. Необхідність підвищення рівня рухової активності молоді було подано у роботі 0. Л. Благій, 0. В. Андрєєвої [1]. Високу ефективність використання засобів кросфіту для підвищення рівня фрізичної підготовленості єдиноборців було науково підтверджено дослі- дженнями E. Cherepov, R. Shaikhetdinov [13]. M. Caloglu, 0. Yüksel [12] y своїх дослідженнях вказують на підвищення рівня анаеробних можливостей організму та силових якостей борців унаслідок використання системи кросфіт. Існує ряд наукових досліджень, які вказують на значну позитивну динаміку основних фрізичних якостей курсантів-десантників після впровадження засобів кросфріту в освітній процес фозичного виховання Військової академії (м. Одеса) [10, 11].

Дослідження виконано відповідно до плану наукової та науково-технічної діяльності Національного університету оборони України імені Івана Черняховського на 2020-2025 рр., у науководослідній роботі науково-дослідного центру проблем фрізичного виховання, спеціальної фрізичної підготовки і спорту навчально-наукового інституту фрізичної культури та спортивно-оздоровчих технологій за темою «Розвиток військово-прикладних навичок та стресостійкості військовослужбовців засобами кросфріту» (номер держреєстрації 0121U111766).

Мета дослідження - визначити вплив засобів кроссріту на фрізичну та профресійно-прикладну підготовку військовослужбовців строкової служби механізованих підрозділів Сухопутних військ.

Методи дослідження: аналіз науково-методичної літератури, теоретичні, емпіричні, експериментальні і статистичні методи.

Результати дослідження та їх обговорення. Перевірку та оцінювання рівня фрізичної підготовленості військовослужбовців проводили за допомогою стандартних рухових тестів, які використовують у Сухопутних військах Збройних сил України [6, 9].

Для оцінювання спеціальної підготовки використовували біг на 1100 м з подоланням смуги перешкод у складі підрозділу, включаючи командирів підрозділів та командира роти включ- но, з особистою зброєю і протигазом Під час виконання вправи дозволяється взаємодопомога без передачі зброї та інших предметів спорядження. Час підрозділу визначається за останнім військовослужбовцем. За норму для військовослужбовців до шести місяців служби брали 5,55 хв, після шести місяців - 5,45 хв.

Для оцінювання витривалості використовували марш-кидок на 5 км у складі підрозділу. Оцінку виставляли за умови прибуття підрозділу на фініш у повному складі з відстанню між військовослужбовцями не більше 50 м. Під час виконання вправи дозволяється взаємодопомога без передачі зброї, протигаза та інших предметів спорядження. Час подолання дистанції підрозділом визначається за останнім військовослужбовцем. За норму для військовослужбовців до і після шести місяців служби брали 28 хв.

Для оцінювання професійно-прикладної підготовки використовували ряд тестових завдань. Загальну контрольну вправу виконували на смузі перешкод без зброї. Дистанція їі - 400 м. Вихідне положення - стоячи в траншеї: кинути гранату масою 600 г на 20 м, по цегляній стінці (проломах) або по площі $(2,6 \times 1$ м) перед стінкою (зараховується пряме попадання); у разі непопадання в ціль першою гранатою продовжувати метання (не більше трьох гранат) до ураження цілі; за непопадання гранати до результату на фініші додається 5 с. Вистрибнути із траншеї і пробігти 100 м по доріжці в напрямку до лінії початку смуги; оббігти прапорець і перестрибнути рів шириною 2,5м; пробігти проходами лабіринту; подолати паркан; залізти по вертикальній драбині на другий (зігнутий) відрізок зруйнованого моста; пробігти по балках, перестрибнути через рів і зіскочити на землю із положення стоячи 3 кінця останнього відрізка балки; подолати три щаблі зруйнованої драбини й обов'язково торкнутися двома ногами землі між щаблями, пробігти під четвертим щаблем; пролізти в пролом стінки; зіскочити в траншею; пройти по ходу сполучення; вискочити із колодязя; стрибком подолати цегляну стінку; вибігти по похилій драбині на 
четвертий щабель і збігти по щаблях зруйнованої драбини; залізти по вертикальній драбині на балку зруйнованого моста; пробігти по балці, перестрибнути через рови і збігти по нахиленій дошці; перестрибнути рів шириною 2 м, пробігти 20 м, оббігти прапорець і пробігти в зворотному напрямку 100 м по доріжці. За норму для військовослужбовців до і після шести місяців служби брали 2,30 хв.

Використовували човниковий біг $6 \times 100$ м, за норму для військовослужбовців до шести місяців служби брали 2,45 хв, після шести місяців 2,40 хв.

Для оцінювання спеціальної підготовки використовували метання гранати Ф-1 на дальність та точність. Маса гранати 600 г. Метання виконують 3 автоматом у руці у коридорі шириною 10 м від лінії метання, довжиною 2 м. Коридор розмічають через 5 м паралельними білими лініями. Час на метання - 1 хв, за норму для військовослужбовців до і після шести місяців брали 35 м. Для метання на точність у ціль - коло з діаметром 3 м, відстань до цілі 35 м, час на метання - 30 с. Надають три спроби, за норму для військовослужбовців до і після шести місяців служби брали одне влучання.

Тестування військовослужбовців строкової служби проводили під час планових занять та в години спортивно-масової роботи.

Всю отриману в ході дослідження цифрову інформацію обробляли 3 використанням комп'ютерного пакета прикладних програм для обробки статистичної інформації Statistica 10.0 (StatSoft, Inc., США). Нами використано одновимірний статистичний аналіз, який передбачав обчислення середнього арифметичного, середнього квадратичного відхилення, коефіцієнта варіації. Достовірність відмінностей визначали за модифікованим t-критерієм Стьюдента для зв'язаних вибіркових сукупностей. Для оцінювання впливу засобів кроссріту на фізичну та професійно-прикладну підготовку військовослужбовців строкової служби за кожним з досліджуваних показників було розраховано темпи приросту за отриманими середні- ми даними, використовуючи формулу Мейнерта. Вірогідність для всіх досліджень була встановлена на рівні не нижче $p<0,05$.

Наукове дослідження проводили на базі 169-го навчального центру Сухопутних військ Збройних сил України. В досліджені брали участь 850 військовослужбовців строкової служби основних спеціальностей механізованих підрозділів Сухопутних військ, середній вік - становив 19,2 року.

Попередній контроль рівня фрізичної та професійно-прикладної підготовки було проведено на четвертому місяці строкової служби військовослужбовців. Основною його метою було визначення ступеня відповідності військовослужбовців вимогам, які висувають умови та характер сучасного бою. Аналіз отриманих результатів, які представлено в таблиці 1, вказує на низький рівень розвитку усіх рухових якостей у військовослужбовців строкової служби. Середньогрупові результати нижче середнього рівня Попередній контроль спеціальних та військово-прикладних вправ, результати яких представлено в таблиці 1 , вказують на низький рівень виконання деяких контрольних вправ. Звертає на себе увагу той факт, що 28,4 \% (n = 241) військовослужбовців строкової служби не можуть подолати перешкоду «стінка» висотою 1,1 м, шириною 2,6 м і товщиною 0,4 м 3 двома проломами через недостатній розвиток гнучкості, 20,9\% $(\mathrm{n}=178)$ осіб втрачають час, долаючи перешкоду (верхній пролом розміром 0,5 × 0,6 м на висоті 0,35 м від землі з прилеглою до неї площею $1 \times 2,6$ м). Відсутність у $20,4 \%(n=173)$ військовослужбовців навичок лазіння по вертикальній драбині та координації під час бігу по балках призводить до суттєвого зниження загального результату, а невірна техніка бігу проходами лабіринту у $30,4 \%$ ( $n=258)$ осіб веде до порушення дихання, що також має загальний негативний вплив. На першому етапі дослідження було виявлено $43,6 \%$ ( $n=371)$ осіб з низькими індивідуальними результатами влучності у метанні гранати в ціль, однією із суттєвих причин $€$ відсутність навички, низькій рівень силових якостей, порушення техніки виконання вправи.

Подолання перешкод є одним із базових елементів у фрізичній підготовці військовослужбовців в усіх арміях світу [9]. Тому під час навчальнотренувальних занять 3 фрізичної підготовки потрібно велику увагу приділяти розвитку окремих рухових якостей, доводячи їх до автоматизму, та розвивати вміння миттєвого переходу під час бою з одних прийомів на інші. Відомо, що ступінь зниження боєздатності військовослужбовців у ході виконання бойових завдань визначається величиною і характером навантажень, спеціальною виучкою, рівнем фрізичної підготовленості, фрізичного розвитку, станом здоров'я та іншими фракторами. За інших рівних умов важливе, а у ряді випадків вирішальне, значення має рівень фізичної підготовленості військовослужбовців.

Одним із реальних шляхів модернізації змісту та структури просресійної підготовки військовослужбовців, які будуть враховувати усі складові та сприяти вдосконаленню практичних умінь і навичок, є суттєва зміна засобів і методів підготовки. Найбільш популярним та ефективним засобом спортивної діяльності, який містить елементи гирьового спорту, важкої атлетики, спортивної гімнастики, легкої атлетики, плавання, велоспорту, атлетичної гімнастики, є система кросффіт.

3 урахуванням результатів попереднього контролю фрізичної підготовки військовослужбовців строкової служби нами було розроблено та запропоновано програму, яка містить засоби кроссріту. У ході складання програми ми враховували вихідний рівень функціональних можливостей організму військовослужбовців, який виступає основою для визначення обсягу та інтенсивності фрізичного навантаження. В програмі було передбачено дотриманням принципів поступовості збільшення фізичного навантаження та єдності загальної, спеціальної та технічної підготовки з урахуванням факторів довгострокової біологічної адаптації систем організму до зовнішніх тренувальних дій. Програма розрахована на 4 години обов'язкових 
Т а б л и ц я 1. Динаміка показників фізичної підготовленості військовослужбовців основних спеціальностей механізованих підрозділів Сухопутних військ Збройних сил України під впливом занять кроссрітом, $(n=850)$

\begin{tabular}{|c|c|c|c|c|c|c|}
\hline \multirow{2}{*}{ Показник } & \multicolumn{2}{|c|}{$\begin{array}{c}\text { Результати на 4-му місяці } \\
\text { служби }\end{array}$} & \multicolumn{2}{|c|}{$\begin{array}{l}\text { Результати на 10-му місяці } \\
\text { служби }\end{array}$} & \multirow{2}{*}{$\pm \Delta, \%$} & \multirow{2}{*}{$\mathbf{p}$} \\
\hline & $x$ & s & $x$ & s & & \\
\hline \multicolumn{7}{|c|}{ Рухові тести } \\
\hline Біг на 1000 м, хв & 4,45 & 0,55 & $4,12^{\star}$ & 0,23 & 7,4 & $p<0,05$ \\
\hline Біг на 100 м, с & 15,7 & 0,91 & $14,9^{*}$ & 0,13 & 5,1 & $p<0,05$ \\
\hline Біг на 3000 м, хв & 16,01 & 2,04 & $15,43^{*}$ & 1,26 & 3,6 & $p>0,05$ \\
\hline Підтягування на перекладині, разів & 6,4 & 2,13 & $10,3^{* *}$ & 1,04 & 60,9 & $p<0,01$ \\
\hline $\begin{array}{l}\text { Згинання та розгинання рук в упорі } \\
\text { лежачи за } 2 \text { хв, разів }\end{array}$ & 41,87 & 13,59 & $64,8^{\star *}$ & 5,01 & 54,8 & $p<0,01$ \\
\hline $\begin{array}{l}\text { Піднімання тулуба з положення лежачи } \\
\text { за } 2 \text { хв, разів }\end{array}$ & 62,9 & 10,37 & $85,3^{\star *}$ & 3,15 & 35,6 & $p<0,01$ \\
\hline Стрибок угору з місця, см & 28,2 & 5,89 & $37,9^{\star \star}$ & 2,29 & 34,4 & $p<0,01$ \\
\hline Стрибок у довжину з місця, см & 175,9 & 21,26 & $238,4^{\star}$ & 14,87 & 35,5 & $p<0,05$ \\
\hline \multicolumn{7}{|c|}{ Спеціальні та військово-прикладні вправи } \\
\hline $\begin{array}{l}\text { Біг на } 1100 \text { м з подоланням смуги пе- } \\
\text { решкод у складі підрозділу, хв }\end{array}$ & 6,11 & 0,47 & $5,43^{\star *}$ & 0,35 & 11,1 & $p<0,01$ \\
\hline Марш-кидок на 5 км, хв & 28,36 & 2,14 & $28,05^{\star}$ & 0,39 & 3,2 & $p>0,05$ \\
\hline $\begin{array}{l}\text { Загальна контрольна вправа на смузі } \\
\text { перешкод, хв.С }\end{array}$ & 2,45 & 0,38 & $2,23^{*}$ & 0,17 & 8,9 & $p<0,05$ \\
\hline Човниковий біг $6 \times 100$ м, хв & 2,54 & 0,26 & $2,38^{*}$ & 0,13 & 6,3 & $p<0,05$ \\
\hline Метання гранати Ф-1 на дальність, м & 33,7 & 6,18 & $35,7^{*}$ & 36,8 & 5,9 & $p<0,05$ \\
\hline $\begin{array}{l}\text { Метання гранати Ф-1 на точність, влу- } \\
\text { чань }\end{array}$ & 0,58 & 0,13 & $0,79^{\star *}$ & 0,08 & 36,2 & $p<0,01$ \\
\hline
\end{tabular}

Примітка: $\pm \Delta, \%$ - різниця між 4-м та 10-м місяцем служби;

Примітка: * різниця статистично значуща на рівні $p<0,05$; ** різниця статистично значуща на рівні $p<0,01$

занять з фрізичної підготовки на тиждень, використання окремих елементів кроссріту при щоденних заняттях ранковою зарядкою та під час проведення спортивно-масових заходів і самостійних занять. Ефрективність запропонованої програми визначали у військовослужбовців на десятому місяці служби (див. табл. 1).

Використання вправ 3 кросфріту на обов'язкових заняттях з фрізичної підготовки становить 50-60 \% загального обсягу, а всі засоби були поєднані 3 технічною та тактичною підготовкою. Як головний метод під час занять було використано метод екстенсивних інтервальних вправ. Такий підхід дав можливість отримати значний позитивний приріст результатів у тестах, які характеризують швидкість, витри- валість, силу, швидкісно-силові якості. Не відбулося вірогідних ( $p>0,05)$ змін у показниках з бігу на 3000 м, хоча час подолання дистанції у військовослужбовців строкової служби зменшився на 3,6 \%.

Використання великого арсеналу стрибкових вправ, зокрема стрибків у довжину, у висоту з положення сидячи, на платформу висотою $50 \mathrm{~cm}$ 3 положення сидячи, присідання зі стрибками угору, згинання і розгинання рук у різних модифікаціях (з плесканням у долоні) різних положень рук (широкий, вузький хват тощо), комплекс «бурпі», вправи з канатом у руках, дали значний позитивний ефект на такі рухові якості, як сила, вибухова сила та силова витривалість. Як видно з таблиці 1, у військовослуж- бовців вірогідно ( $p<0,01)$ збільшились результати у тестах в підтягуванні на перекладині на 60,9 \%, згинання і розгинання рук в упорі лежачи - на $54,8 \%$, у результатах стрибкових тестів на 34,4 та 35,5 \% відповідно.

Такий приріст середньогрупових результатів у військовослужбовців обумовлений щоденним використанням базових засобів кросфіту під час ранкової зарядки. Обов'язковими були вправи 3 власною вагою тіла, статичні вправи, вправи з обтяженням, на гімнастичних снарядах, аеробного характеру.

Використання засобів кросфріту як основного засобу фрізичної підготовки дало значний позитивний ефект на результати виконання спеціальних 
та військово-прикладних вправ (див табл. 1).

У годинах спортивно-масової роботи та під час фрізичних тренувань у процесі навчально-бойової діяльності для розвитку спеціальних фрізичних якостей до програми було включено шість обов'язкових вправ, а саме: випади на одну ногу з обтяженням (на спині за головою, на плечах, на грудях, у руках, на прямих руках угорі, перед собою); присідання 3 кидком медбола в ціль (за 30 с.); присідання 3 обтяженням; тяга штанги у нахилі; стрибки зі скакалкою 1 хв; кидки медбола на підлогу та в стіну. Усі вправи модернізувалися і доповнювалися в умовах створення певних завдань.

На десятому місяці служби під час повторноготестування військовослужбовців було виявлено статистично значущу різницю $(p<0,05 ; p<0,01)$ у переважній більшості досліджуваних показників, а середньогрупові результати знаходились у межах нормативних вимог. Як видно з таблиці 1, у військовослужбовців покращились результати у тестах 3 військовоприкладних вправ: бігу на 1100 м 3 подоланням смуги перешкод у складі підрозділу на 11,1 \%; подоланні загальної контрольної вправи на смузі перешкод - на 8,9 \%; човникового бігу $6 \times 100$ м на 6,3\%; метанні гранати на точність та дальність - на 36,2 \% та 5,9 \% відповідно. Єдина контрольна вправа - марш-кидок на 5000 м, - яку переважна більшість військовослужбовців строкової служби не змогла виконати, характеризує передовсім спеціальну витривалість і потребує значно тривалішого часу для її розвитку та вдосконалення.

Висновки. Використання високоінтенсивних багатофуннціональних засобів кроссріту протягом педагогічного експерименту сприяло позитивній динаміці рівня фрізичної та спеціальної підготовки військовослужбовців строкової служби основних спеціальностей механізованих підрозділів Сухопутних військ. Використані нами протягом педагогічного експерименту методичні прийоми дозволили диференціювати інтенсивність та тривалість ффізичних навантажень, що дало змогу уникнути стану перенапружен- ня та зриву адаптації до фрізичних навантажень у військовослужбовців строкової служби. Комплекси вправ, які увійшли до розробленої програми, мали позитивний вплив на формування та вдосконалення прикладних рухових умінь та навичок, а також розвиток важливих рухових якостей. Системна форма організації навантажень різної модальної спрямованості сприяла значному підвищенню спеціальної та фрізичної підготовки військовослужбовців строкової служби.

Конфлікт інтересів. Автори заявляють, що відсутній будь-який конфрлікт інтересів

\section{ЛІТЕРАТУРА}

1. Благій ОЛ, Андрєєва ОВ. Рухова активність як фактор формування здорово го способу життя учнівської молоді. Актуальн проблеми фізичного виховання, реабілітації, спорту та туризму. Матеріали 3 Міжнар. наук. практ. конф.; 2011. Запоріжжя: КПУ; 2011.27, 28

2. Петрачков ОВ. Вимоги сучасного бою до рівня фізичної підготовленості військовослужбовців механізованих підрозділів Сухопутних військ. Вісник Національного університету оборони України. 2011; 6 (25): 84-90.

3. Петрачков ОВ. Диференціація вимо щодо фізичної підготовленості молодого попо внення на різних етапах його навчально-бойово підготовки. Науковий часопис Національного педагогічного університету імені М. П. Драго манова. 2011; (11): 180-184.

4. Петрачков ОВ. Вплив фракторів на ефрективність процесу бойової підготовки військовослужбовців Сухопутних військ. Науковий вісник Національного університету біоресурсі і природокористування України. 2013; 192 (2): 66-72.

5. Петрачков ОВ. Особливості моделі по етапної просесійно-прикладної підготовки військовослужбовців в навчальному центрі Су хопутних військ. Вісник Національного університету оборони України. 2013;1 (32): 124-129.

6. Петрачков ОВ. Особливості системи оцінювання ффізичної підготовленості військовослужбовців провідних країн світу. Педагогічна освіта: теорія і практика КПНУ ім. І. Огієнка. 2013;15: 82-89.

7. Петрачков ОВ, Фіногенов ЮС. Модельн характеристики різних рівнів фрізичної підготовленості курсантів механізованих підрозділів навчального центру Сухопутних військ. Вісник Національного університету оборони України. 2013:4 (35): 167-172.

8. Петрачков 0, Ярмак 0. Використання засобів функціонального тренінгу у підвищенн показників фізичного стану юнаків. Теорія і ме тодика фіз. виховання і спорту. 2021; 1: 50-54. DOI: 10.32652/tmfvs.2021.1.50-54

9. Шемчук В, Петрачков О, Вербин Н, Жембровський С. Організація та методика проведення занять із подолання перешкод: навч.-метод. посіб. Київ. Національний університет оборони України імені Івана Черняховського. 2021. 72.
10. Ягодзінський ВП. Кросфіт як ефективний засіб фрізичної підготовки військовослужбовців високомобільних десантних військ. Науковий часопис Національного педагогічного університету імені М. П. Драгоманова. 2017; 12 (94) 17: 134-138.

11. Ягодзінський ВП. Покращання функціональних можливостей курсантів засобами кросфіту. Науковий часопис Національного педагогічного університету імені М. П. Драгоманова. 2018;11(105) 18: 137-142.

12. Caloglu M, Yüksel O. The effect of CrossFit training on anaerobic power and dynamic balance of greco-roman and freestyle wrestlers. International Journal of Applied Exercise Physiology. 2020; 9 (1):122-132.

13. Cherepov E., Shaikhetdinov R. Effectiveness of functional training during physical conditioning of students practicing martial arts. Journal of Physical Education and Sport. 2016; 2: 510512.

14. Oderov A, Romanchuk S, Fedak S, Kuznetsov M, Petruk A, Dunets-Lesko A, Lesko 0, Olkhovyi 0 . Innovative approaches for evaluating physical fitness of servicemen in the system of professional training. Journal of physical education and sport. 2017; 17: 23-27.

\section{LITERATURE}

1. Blahii OL, Andrieieva OV. Physical activity as a factor affecting development of a healthy lifestyle in school students. Actual issues of physical education, rehabilitation, sports and tourism. Proceedings of the 3rd Internat. scient.pract. conf.; 2011. Zaporizhzhia: CPU; 2011.27, 28.

2. Petrachkov OV. Requirements of modern combat action to the level of physical fitness of servicemen of the Land Forces motorized units. Visnyk Natsionalnoho universytetu oborony Ukrayiny. 2011; 6 (25): 84-90

3. Petrachkov OV. Differentiation of requirements for physical fitness in young recruits at different stages of their combat training. Naukovyi chasopys of M.P.Dragomanov National Pedagogical University. 2011; (11): 180-184

4. Petrachkov OV. Factors affecting the effectiveness of the process of combat training of servicemen of the Land Forces. Naukovyi visnyk Natsionalnoho universytetu bioresursiv i pryrodokorystuvannia Ukrayiny. 2013; 192 (2): 66-72.

5. Petrachkov OV. Features of the model of stage-by-stage professional and applied training of servicemen in the training center of the Land Forces. Visnyk Natsionalnoho universytetu oborony Ukrayiny. 2013:1 (32): 124-129.

6. Petrachkov OV. Features of the system of physical fitness assessment of servicemen of the leading countries of the world. Pedagogical Education: Theory and Practice. KamianetsPodilskyi Ivan Ohiienko National University. 2013;15: 82-89.

7. Petrachkov OV, Finogenov YuS. Model characteristics of different levels of physical fitness in cadets of motorized units of the training center of the Land Forces. Visnyk Natsionalnoho universytetu oborony Ukrayiny. 2013;4 (35): 167172.

8. Petrachkov 0, Yarmak 0. Usage of functional training means to increase physical status indices of young boys. Theory and methods of physical education and sports. 2021; 1: 50-54. DOI: 10.32652/tmfvs.2021.1.50-54 
9. Shemchuk V, Petrachkov 0, Verbyn N Zhembrovskyi S. Organization and methods of conducting classes on obstacle crossing: educ.method. manual. Kyiv. National Defense University of Ukraine named after Ivan Chernyakhovsky. 2021. 72.

10. Yagodzinskyi VP. Crossfit as an effective means of physical training of highly mobile airborne troops. Naukovyi chasopys of M.P.Dragomanov National Pedagogical University. 2017; (94): 134-138.

11. Yagodzinskyi VP. Improving the functional abilities of cadets using crossfit training. Naukovyi chasopys of M.P.Dragomanov National Pedagogical University. 2018;11(105) 18: 137142.

12. Caloglu M, Yüksel 0 . The effect of CrossFit training on anaerobic power and dynamic balance of greco-roman and freestyle wrestlers. International Journal of Applied Exercise Physiology. 2020; 9 (1):122-132.

13. Cherepov E., Shaikhetdinov R. Effectiveness of functional training during physical conditioning of students practicing martial arts. Journal of Physical Education and Sport. 2016; 2: 510 512.

14. Oderov A, Romanchuk S, Fedak S, Kuznetsov M, Petruk A, Dunets-Lesko A, Lesko O, Olkhovyi 0. Innovative approaches for evaluating physical fitness of servicemen in the system of professional training. Journal of physical education and sport. 2017; 17: 23-27.

\section{ІНФОРМАЦІЯ ПРО АВТОРІВ}

Петрачков Олександр Валерійович orcid.org/0000-0002-6684-1641, apetrachkov77@ukr.net Національний університет оборони України імені Івана Черняховського 03049, Київ, Повітрофрлотський проспект, 28

Ярмак Олена Миколаївна orcid id 0000-0002-6580-6123, yarmak_en@ukr.net Білоцерківський національний аграрний університет 09117, Київська область, Біла Церква, Соборна пл., 8/1

Білошицький Василь Васильович orcid.org/0000-0001-6083-2579, belv10@ukr.net Національний університет оборони України імені Івана Черняховського 03049, Київ, Повітрофрлотський проспект, 28

\section{INFORMATION ABOUT THE AUTHORS}

Petrachkov Oleksandr orcid.org/0000-0002-6684-1641, apetrachkov77@ukr.net

The National Defense University of Ukraine named after Ivan Cherniakhovskyi 03049, Kyiv, Povitroflotsky Ave, 28

Yarmak Olena orcid id 0000-0002-6580-6123, yarmak_en@ukr.net

Bila Tserkva National Agrarian University

09117, Kyiv region, Bila Tserkva, Soborna sq. 8/1

Biloshitskiy Vasiliy orcid.org/0000-0001-6083-2579, belv10@ukr.net

The National Defense University of Ukraine named after Ivan Cherniakhovskyi 03049, Kyiv, Povitroflotsky Ave, 28 